\title{
Assessment of Microbial Adhesion on Provisional Crown Material after Polishing with Different Polishing Agents - An In-Vitro Study
}

Research Article

\section{Saishree Anchana Rajeswaran ${ }^{1}$, Dhanraj M Ganapathy ${ }^{2}$, Subhabrata Maiti ${ }^{*}$, Smiline Girija $\mathrm{AS}^{4}$}

${ }^{1}$ Undergraduate Student, Saveetha Dental College and Hospitals, Saveetha Institute of Medical and Technical Sciences Saveetha University, Chennai-600077, Tamilnadu, India.

${ }^{2}$ Professor and Head of Department, Department of Prosthodontics, Saveetha Dental College And Hospitals, Saveetha Institute Of Medical And Technical Sciences, Saveetha University, Chennai-600077, Tamilnadu, India.

${ }^{3}$ Assistant Professor, Department of Prosthodontics, Saveetha Dental College and Hospitals, Saveetha Institute of Medical and Technical Sciences Saveetha University, Chennai-600077, Tamilnadu, India.

${ }^{4}$ Associate Professor, Department of Microbiology, Saveetha Dental College And Hospitals, Saveetha Institute Of Medical And Technical Sciences, Saveetha University, Chennai-600077, Tamilnadu, India.

\section{Abstract}

Aim: To assess themicrobial culture on provisional crown material polished with different polishing agents.

Materials and Methods: Discs made of Pro-temp provisional crown material, of a uniform size, were polishes using Rouge, Polishing paste and Pumice, i.e. three different polishing agents. They were then disinfected and immersed in a Streptococcus mutansbacterial broth, and were incubated for 24 hours. The biofilm formed on the discs post incubation were smeared on agar petri plates, to obtain subcultures that can be used for colony counting and determining the extent of biofilm formation on each disc. Results: There is a significant difference in the method of polishing employed and the bacterial adherence and colonisation on the surface of the provisional crown material.

Conclusion: Rouge is a better polishing agent, followed by polishing paste, and then pumice, which is inferred from the microbial colonisation on the discs polished with respective polishing agents.

Clinical significance: Provisional crowns, also known as interim crowns, are devices placed temporarily, until a permanent replacement is constructed, for protecting the affected tooth, preventing teeth shifting, maintaining aesthetics, and in keeping sensitivity at bay. Also, it is known that microbial colonisation is favoured by rough or irregular surfaces. Thus, with the extensive microbial flora of the oral cavity, it is indispensable that the surface roughness of any material or appliance, that is to be placed inside the oral cavity, must be finished and polished to support least microbial adhesion and growth. The present study aims to assess the effect of various polishing agents on provisional crown material to study the extent of microbial colonisation over it.

Keywords: Original Study; Microbial Colonisation; Biofilm; Provisional Crown; Streptococcus Mutans; Rouge; Polishing Paste; Pumice.

\section{Introduction}

With the expanding use of fixed prostheses in current times, considerations into the development of provisional crowns is of growing interest worldwide. As a part of the standard prosthetic therapy, prosthetic crowns play an important role in tooth preparation [1] and in luting the final restoration that provides protection against any form of physical, chemical and thermal traumatic factors on tooth pulp tissues [2]. They help maintain occlusion and space [3], and facilitate speech and masticatory functions in the interim period, before fixing the final crown, thus contributing to strength and aesthetics, which are certain essential aspects of treatment success [4]. Previous studies also establish their role in the maintenance of periodontal health and guided tissue healing [5]. Besides, provisional crowns are guide templates for fabricating the actual crowns [6]. They also prove to be psychological

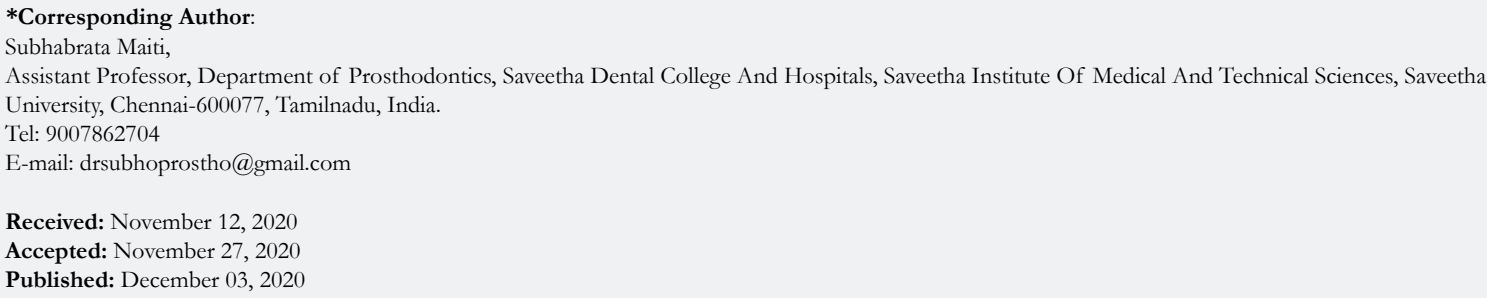

Citation: Saishree Anchana Rajeswaran, Dhanraj M Ganapathy, Subhabrata Maiti, Smiline Girija AS. Assessment of Microbial Adhesion on Provisional Crown Material after Polishing with Different Polishing Agents - An In-Vitro Study. Int J Dentistry Oral Sci. 2020;S5:02:006:27-31. doi: http://dx.doi.org/10.19070/2377-8075-SI02-05006

Copyright: Subhabrata Maiti ${ }^{\circ}$ 2020. This is an open-access article distributed under the terms of the Creative Commons Attribution License, which permits unrestricted use, distribution and reproduction in any medium, provided the original author and source are credited. 
management aids in patients undergoing the treatment process [7]. The nuance over here lies in the preparation of a crown, permitting self-cleaning, with a well-polished, stain resistant and plaque resistant finish [8].

The polymer based temporary material used earlier, for fabricating provisional crowns, is polymethyl methacrylate (PMMA) mixed with a methyl methacrylate monomer (MMA) liquid which resulted in an exothermic setting reaction that necessitated the timely removal of the temporary restoration lest it causes pulpal damage [9]. Currently, the most successful and widely used temporary crown material is the bis-acrylate composite, Protemp. With improved mechanical properties, reduced configuration factor, lowered setting temperature, better colour stability, good polishability, and a strength equivalent to that of composites, the composition of Protemp includes organic resins and inorganic fillers [10]. Bisphenol-A-glycidyl methacrylate (bis-GMA) andtriethylene glycol dimethacrylate (TEGDMA) are some Bowen resin derivatives which are used as the organic resin [11] while inorganic fillers including zirconia-silica and fumed silica, account for about half of the composition by weight [12].

A common oral pathogen is the $S$. mutans [13], which is why this particular pathogen was considered for the study. Even though bacterial proliferation is responsible for plaque formation, the initial adhesion of bacteria itself is caused by surface irregularities and roughness [14]. In highly irregular surfaces, due to inadequate salivary flow, bacteria can adhere to the surface of the intra-oral prosthesis, better [15]. Moreover, the extent of bacterial colonisation on any surface is determined by surface characteristics like hydrophobicity and surface charge [16]. On polishing using polishing agent slike rouge, polishing, paste, pumice stone, gypsum, chalk, tripoli, garnet, cuttle, tin oxide etc.,the surface is rendered smooth [17], making this procedure crucial to any prosthesis placed in the oral cavity.There have been previous studies [18] which illustrated various methods for quantifying bacterial adhesion to dental structures. These methods included electron microscopy, radiolabelling, fluorescence testing and direct plate counting.

Thus, with the hypothesis that various polishing methods will have a different impact on the surface roughness of provisional crown materials, the study was conducted to test the efficacy of the polishing agents used, namely, rouge, polishing paste and pumice.

\section{Materials and Methods}

\section{Fabrication of discs with Protemp}

With pro-temp being used commonly nowadays, for the fabrication of provisional crowns, the present study used the same material for fabricating the sample discs. 20 discs of uniform size were fabricated using putty moulds. Gross surface irregularities were removed using burs for shaping, and fine sand paper, for polishing.

\section{Polishing of fabricated discs}

Following this, the prepared discs were subjected to fine polishing using three polishing agents, Rouge, Polishing paste and Pumice.
Among the 20 discs prepared, 5 were polished with rouge, 5 with polishing pasteand 5 with pumice. The remaining 5 were control discs, not subjected to polishing.

\section{Culture of $S$. mutans and introduction of discs into culture}

All the discs post polishing,were disinfected using surgical spirit, to prevent contamination. Parallelly, a $200 \mathrm{ml}$ liquid culture of S. mutans in trypticase soy broth was prepared and incubated at $37^{\circ} \mathrm{C}$ for 24 hours. The following day, the disinfected discs were placed in sterile containers, each with $10 \mathrm{ml}$ of the $\mathrm{S}$. mutans broth. These containers were incubated again, at $37^{\circ} \mathrm{C}$ for 24 hours. The next day, the incubated discs were retrieved and cleaned with saline. The discs were vortexed for obtaining bacterial colonies formed on the discs as biofilm, which were then swabbed with sterile cotton swabs and streaked onto agar plates, and were labelled accordingly. The streaked plated were then incubated at $37^{\circ} \mathrm{C}$ for 48 hours. Post-incubation, the plates that showed microcolonies of S. mutanswere observed and colonies were counted (Fig.1). The results obtained were recorded and tabulated. They were also statistically analysed using SPSS v26 (IBM. inc., USA) with the One-way ANOVA and Tukey HSD Post Hoc Tests performed.

\section{Results}

The results pertaining to the microbial colonisation with respect to the polishing agent used on provisional crown material is presented here. Table 1 indicates the mean values of the microbial colonisation for each group, including the control group, on performing the One-way ANOVA test. For discs polished with rouge, a mean of $5.00 \times 10^{3} \mathrm{CFU}$ was obtained. Discs polished with polishing paste showed a mean value of $8.00 \times 10^{3} \mathrm{CFU}$. Further, a mean value of $13.00 \times 10^{3} \mathrm{CFU}$ was found with discs polished with pumice. The control discs gave a mean of $18.00 \times 10^{3} \mathrm{CFU}$ microbial colonies. It is also observed that there is a significant difference between the mean values for each group of polishing agents, which is indicated by a $\mathrm{p}$-value of 0.001 (where $\mathrm{p}<0.05$ ). It is also noted that the least number of microbial colonies was observed on polishing discs with rouge, which is followed by polishing paste, and then pumice (Fig. 2). The control group, being unpolished, showed the greatest number of microbial colonies.

Table 2 is indicative of the comparative mean differences between each polishing agent obtained on performing the Tukey HSD Post Hoc Test. The mean differences were calculated from the mean values of the microbial colonies after polishing the discs with the specific polishing agent. A mean difference of 3.00, which is also significant $(p=0.015)$, is observed between the groups containing discs that were polished with polishing paste and rouge. Discs polished with pumice and rouge gave a mean difference of 8.00, which is also observed to be significant $(p=0.001)$. Further, discs polished with polishing paste and pumice gave a mean difference of 5.00 , which again is significant $(\mathrm{p}=0.001)$. Thereby, the results pertaining to the effect of polishing the discs with each agent, was compared with one another.

\section{Discussion}

On counting the colonies in the petri dishes after incubation, each of the samples showed different results. This complies with the 
Figure 1. Culture on plates post incubation.

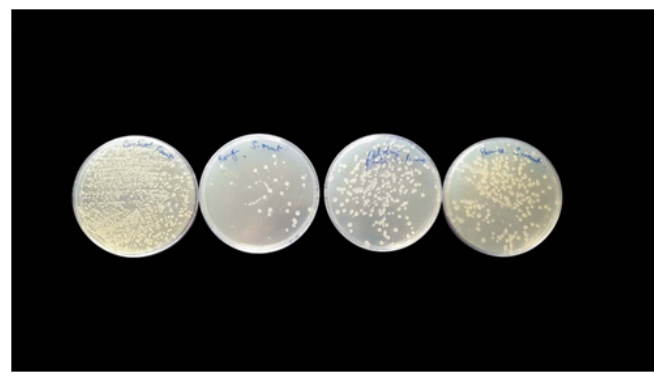

Table 1.

\begin{tabular}{|c|c|c|c|c|c|c|c|}
\hline \multirow[t]{2}{*}{ Group } & \multirow[t]{2}{*}{ Mean } & \multirow[t]{2}{*}{ Std. Deviation } & \multirow{2}{*}{$\begin{array}{l}\text { Std. } \\
\text { Error }\end{array}$} & \multicolumn{2}{|c|}{$\begin{array}{c}\text { 95\% Confidence Interval for } \\
\text { Mean }\end{array}$} & \multirow[t]{2}{*}{ F } & \multirow[t]{2}{*}{ p-value } \\
\hline & & & & Lower Bound & Upper Bound & & \\
\hline Rouge & 5.00 & 0.000 & 0.000 & 5.00 & 5.00 & \multirow{4}{*}{87.111} & \multirow{4}{*}{$0.001^{\mathrm{a}}$} \\
\hline Polishing Paste & 8.00 & 1.581 & 0.707 & 6.04 & 9.96 & & \\
\hline Pumice & 13.00 & 1.581 & 0.707 & 11.04 & 14.96 & & \\
\hline Control & 18.00 & 1.581 & 0.707 & 16.04 & 19.96 & & \\
\hline
\end{tabular}

p-value derived from One-way ANOVA test; asignificant at $\mathrm{p}<0.05$.

Table 2.

\begin{tabular}{|c|c|c|c|}
\hline Group & Mean Difference & Std. Error & p-value \\
\hline Rouge vs Polishing Paste & $-3.000^{\mathrm{b}}$ & 0.866 & $0.015^{\mathrm{a}}$ \\
\hline Rouge vs Pumice & $-8.000^{\mathrm{b}}$ & 0.866 & $0.001^{\mathrm{a}}$ \\
\hline Polishing Paste vs Pumice & $-5.000^{\mathrm{b}}$ & 0.866 & $0.001^{\mathrm{a}}$ \\
\hline
\end{tabular}

${ }^{\mathrm{b}}$ Mean difference is significant at the 0.05 level; $\mathrm{p}$-value derived from Tukey HSD Post Hoc Test; ${ }^{a}$ significant at $\mathrm{p}<0.05$

Figure 2. Mean values for microbial colonies with respect to polishing agents in homogeneous subsets are displayed.

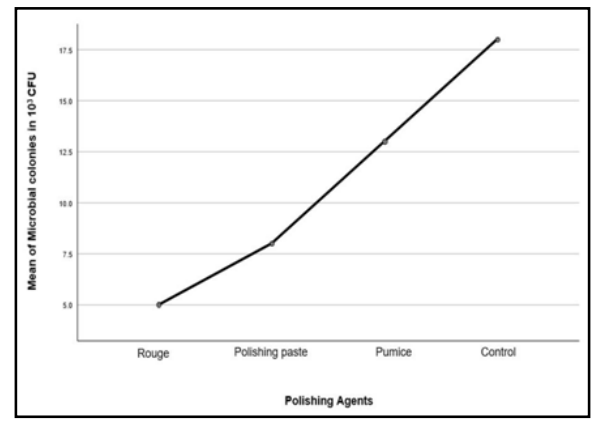

hypothesis that microbial colonisation on the provisional crown material varies with the polishing agent used on it. The mean number of colonies observed in the petri dishes with samples from the discs polished with rouge was $5.00 \times 10^{3} \mathrm{CFU}$. For the discs polished with polishing paste, the mean number of colonies counted from these petri dishes was $8.00 \times 10^{3} \mathrm{CFU}$. The mean number of colonies counted from the petri plated smeared with samples from the discs polished with pumice was $13.00 \times 10^{3}$ CFU. Finally, the control plates showed a mean value of $18.00 \mathrm{x}$ $10^{3}$ CFU. The observed results were represented graphically and were statistically analysed using the One-way ANOVA test to obtain a $\mathrm{p}$ value $<0.05$, indicating that there is a significant difference in the method of polishing employed and the technique dependant bacterial adherence and colonisation on the surface. Besides, the mean difference between the microbial colonisation observed after polishing the discs with a polishing agent, with respect to another polishing agents was parallelly compared using the Tukey HSD Post Hoc Test.

There have been several studies [19], which previously established that the adhesion of oral commensals on the surface of structures introduced into the oral cavity leads to deposition of dental plaque, thus posing as a primary etiological factor to a variety of oral diseases including denture stomatitis, gingival inflammation, and secondary caries. Microscopic examination by Ionescu et al., [20], in his study, showed that microbial colonization begins in the crevices, grooves, or pits on the surface.An occlusal surface with many pits and grooves also promotes greater bacterial colonisation, corresponding to the high surface free energy in such cases. A study by Dantas et al., [21], found that surface roughness and 
bacterial adherence were influenced by manufacturing techniques and finishing/polishing protocols. Besides, in his study, Nestor et al., [22] demonstrated metabolically active bacterial settlements in polished bis-acrylic resin surface areas with surface imperfectionswhich, after polishing, yielded a much more regular surface with only few microorganisms, when observed on an electron microscope.

In fact, considering the material chosen for the present study, Protemp, other specific studies [23] conclude that Protemp allows for exemption from polishing. Instead, rubbing with alcohol after polymerization is sufficient to provide a smooth surface with the oxygen inhibition layer removed. However, the same study also states that, with the use of the material for provisional crowns, polishing becomes a critical step.

From the results, it can be inferred that different polishing agents prevent the colonisation of bacteria on the discs to different degrees. Among all the discs, the ones polished with rouge showed minimum bacterial colonies on sub-culturing. Rouge, composed of $\mathrm{Fe} 2 \mathrm{O} 3$, varies from bright red to a sandy colour, with varying hardness based on the intensity of the colour. Generally, it is used for gross polishing of metals, glass, and stones, and for fine polishing of gold, silver, brass, and steel [24].

In the current study, the second set of discs were polished with Smile-N-Shine polishing paste, with the help of a dental polishing brush attached to a hand piece. Generally, these are prophylactic pastes [25], preferred to be used on teeth and restorations on it. They often contain particulate zirconium silicate, rouge, cuttle, tripoli, cuttle, emery, coarse pumice to prevent roughening surfaces.

The third polishing agent used was pumice powder. Pumice, a light coloured, siliceous material produced by volcanic activity, is used generally for the polishing of tooth enamel, gold foil, dental amalgam and acrylic resins. On comparison of results obtained for each of the polishing agents, it was observed that the maximum bacterial colonisation was on the discs polished with pumice, followed by polishing paste. Hence, rouge was observed to be more effective among the three agents, as it resulted in least microbial colonisation. Besides, when observing the unpolished control discs, there was a manifold increase in biofilm formation. This indicates the importance of polishing as a final procedure that attributes to the success of treatment. However, the study is limited by the fact that the findings are confined to in-vitro conditions.

\section{Conclusion}

From the study, it is determined that rouge is a better polishing agent, followed by polishing paste, and then pumice, which is inferred from the microbial colonisation on the discs polished with respective polishing agents. Thus, it can be concluded that the efficacy of the polishing agent is a major consideration for a dentist when it comes exercising control over the extent of biofilm accumulation on the surface of the prosthesis, thereby ultimately ensuring better treatment.

\section{Clinical Significance}

The accumulation of biofilm on the surface of provisional restorations is associated with and dependant on the roughness of its surface. Moreover, the longer the period that the prosthesis is placed in the oral cavity, the greater is the need for preventing plaque accumulation. Thus, prior to the temporary cementation of the provisional prosthesis it is necessary to render the surface smoothto ensure less bacterial adherence, and thereby, minimize the probabilityof development of caries and periodontitis lesions, and prevent any discoloration. Thus, with respect toa pathological and aestheticview,identifying how finishing and polishing procedures can be made more effective, is a mandate.

\section{References}

[1]. Regish KM, Sharma D, Prithviraj DR. Techniques of fabrication of provisional restoration: an overview. Int J Dent. 2011;2011:134659.Pubmed PMID: 22013441

[2]. Burns DR, Beck DA, Nelson SK; Committee on Research in Fixed Prosthodontics of the Academy of Fixed Prosthodontics. A review of selected dental literature on contemporary provisional fixed prosthodontic treatment: report of the Committee on Research in Fixed Prosthodontics of the Academy of Fixed Prosthodontics. J Prosthet Dent. 2003 Nov;90(5):474-97.Pubmed PMID: 14586312.

[3]. Tahayeri A, Morgan M, Fugolin AP, Bompolaki D, Athirasala A, Pfeifer CS, et al. 3D printed versus conventionally cured provisional crown and bridge dental materials. Dent Mater. 2018 Feb;34(2):192-200.Pubmed PMID: 29110921.

[4]. Kosyfaki P, del Pilar Pinilla Martín M, Strub JR. Relationship between crowns and the periodontium: a literature update. Quintessence Int. 2010 Feb;41(2):109-26.Pubmed PMID: 20165743.

[5]. Turgut S, Bagis B, Ayaz EA, Ulusoy KU, Altintas SH, Korkmaz FM, et al. Discoloration of provisional restorations after oral rinses. Int J Med Sci. 2013 Aug 30;10(11):1503-9.Pubmed PMID: 24046524.

[6]. Abdullah AO, Tsitrou EA, Pollington S. Comparative in vitro evaluation of CAD/CAM vs conventional provisional crowns. J Appl Oral Sci. 2016 MayJun;24(3):258-63.Pubmed PMID: 27383707.

[7]. Patras M, Naka O, Doukoudakis S, Pissiotis A. Management of provisional restorations' deficiencies: a literature review. J Esthet Restor Dent. 2012 Feb;24(1):26-38.Pubmed PMID: 22296692.

[8]. Ozel GS, Guneser MB, Inan O, Eldeniz AU. Evaluation of C. Albicans and S. Mutans adherence on different provisional crown materials. J Adv Prosthodont. 2017 Oct;9(5):335-340.Pubmed PMID: 29142640.

[9]. Melo MA, Guedes SF, Xu HH, Rodrigues LK. Nanotechnology-based restorative materials for dental caries management. Trends Biotechnol. 2013 Aug;31(8):459-67.Pubmed PMID: 23810638.

[10]. Singh A, Garg S. Comparative Evaluation of Flexural Strength of Provisional Crown and Bridge Materials-An Invitro Study. J Clin Diagn Res. 2016 Aug;10(8):ZC72-7.Pubmed PMID: 27656568.

[11]. Liu X, Wang Z, Zhao C, Bu W, Zhang Y, Na H. Synthesis, characterization and evaluation of a fluorinated resin monomer with low water sorption. J Mech Behav Biomed Mater. 2018 Jan;77:446-454. Pubmed PMID: 29028596.

[12]. Guo G, Fan Y, Zhang JF, Hagan JL, Xu X. Novel dental composites reinforced with zirconia-silica ceramic nanofibers. Dent Mater. 2012 Apr;28(4):360-8. Pubmed PMID: 22153326.

[13]. Nicolas GG, Lavoie MC. Streptococcus mutans et les streptocoques buccaux dans la plaque dentaire [Streptococcus mutans and oral streptococci in dental plaque]. Can J Microbiol. 2011 Jan;57(1):1-20.Pubmed PMID: 21217792 .

[14]. Ercoli C, Caton JG. Dental prostheses and tooth-related factors. J Periodontol. 2018 Jun;89 Suppl 1:S223-S236.Pubmed PMID: 29926939.

[15]. Das MP.An approach to low-density polyethylene biodegradation by Bacillus amyloliquefaciens.Int J Pharm Sci. 2013;5(4):690-694.

[16]. Wassmann T, Kreis S, Behr M, Buergers R. The influence of surface texture and wettability on initial bacterial adhesion on titanium and zirconium oxide dental implants. Int J Implant Dent. 2017 Dec;3(1):1-11.

[17]. Sirin Karaarslan E, Bulbul M, Yildiz E, Secilmis A, Sari F, Usumez A. Effects of different polishing methods on color stability of resin composites 
after accelerated aging. Dent Mater J. 2013;32(1):58-67.Pubmed PMID: 23370871

[18]. Sanders DL, Bond P, Moate R, Steer JA. Design and validation of a novel quantitative method for rapid bacterial enumeration using programmed stage movement scanning electron microscopy. J Microbiol Methods. 2012 Dec;91(3):544-50.Pubmed PMID: 23041496.

[19]. Rutkunas V, Sabaliauskas V, Mizutani H. Effects of different food colorants and polishing techniques on color stability of provisional prosthetic materials. Dent Mater J. 2010 Mar;29(2):167-76.Pubmed PMID: 20379027.

[20]. Meule A, Küppers C, Harms L, Friederich HC, Schmidt U, Blechert J, et al. Food cue-induced craving in individuals with bulimia nervosa and bingeeating disorder. PLoS One. 2018 Sep 13;13(9):e0204151.

[21]. Dantas LC, Silva-Neto JP, Dantas TS, Naves LZ, das Neves FD, da Mota AS. Bacterial adhesion and surface roughness for different clinical techniques for acrylic polymethyl methacrylate. International journal of dentistry. 2016 Jul 19;2016.
[22]. Lara-Jara NU, Romo-Ramírez GF, del Pilar Goldaracena-Azuara M, AragónPiñ A, Girón CB, Méndez-González MV, González-Amaro AM. Effect of Polishing Procedure on the Roughness and Bacterial Adhesion of Provisional Restorative Materials. Microscopy Research. 2018 Jul 24;6(2):9-18.

[23]. Tupinambá ÍVM, Giampá PCC, Rocha IAR, Lima EMCX. Effect of different polishing methods on surface roughness of provisional prosthetic materials. J Indian Prosthodont Soc. 2018 Apr-Jun;18(2):96-101.Pubmed PMID: 29692561.

[24]. Rao DC, Kalavathy N, Mohammad HS, Hariprasad A, Kumar CR. Evaluation of the surface roughness of three heat-cured acrylic denture base resins with different conventional lathe polishing techniques: A comparative study. J Indian Prosthodont Soc. 2015 Oct-Dec;15(4):374-80.Pubmed PMID: 26929542.

[25]. Sarikaya I, Güler AU. Effects of different polishing techniques on the surface roughness of dental porcelains. J Appl Oral Sci. 2010 Jan-Feb;18(1):10-6. Pubmed PMID: 20379676. 